\title{
Research Results for a New Onion Seed Drill
}

\author{
Abdirasuli A. Ibragimov, \\ Dr.Sc.(Eng.), senior researcher, \\ e-mail: abirasul_82@mail.ru; \\ Asamiddin K. Karakhanov, \\ Ph.D.(Eng.), head of the laboratory; \\ Abdukarim A. Abdurakhmanov, \\ Ph.D.(Eng.), senior researcher, \\ e-mail:3abdukarim@mail.ru;
}

\author{
Akmal E. Eshdavlatov, \\ doctoral student, \\ e-mail: aeshdavlatov91@mail.uz; \\ Pulat A. Uteniyazov, \\ junior researcher, \\ e-mail: paytbaev@list.ru; \\ Adham A. Khadzhiev, \\ junior researcher, \\ e-mail: adham.hadjiev@bk.ru
}

Research Institute of Agricultural Mechanization, Yangiyul, Republic of Uzbekistan

\begin{abstract}
For sowing small seeds of vegetables, in particular onions, special seeders are used. They are not produced in the Republic of Uzbekistan, while many different pneumatic seeders are produced abroad. The authors note that foreign samples are complex in design, not adapted to local soil and climatic conditions, cannot provide even seed placement on ridges, and the cost of the seeders themselves and service are very high. (Research purpose) To develop a vegetable seeder in relation to the soil and climatic conditions of Uzbekistan, to determine the seeding rate of onion seeds depending on the length of the active part of the seed reel, to evaluate the formation quality of sowing ridges and irrigation furrows. (Materials and methods) The authors determined the sowing rate by turning the seeder drive wheel at a given length of the active part of the sowing reel and collecting the sown seeds in cups with further weighing. The quality of sowing ridges and irrigation furrows formation was evaluated by the method of profiling the field before and after the seeder's pass. (Results and discussion) The authors developed a vegetable seeder that performed three operations in one pass: cutting irrigation furrows, forming sowing ridges of a trapezoidal shape and sowing onion seeds and other small-seeded vegetable crops in a three-row tape method in each tape. They found that the dependence of the seeding rate on the length of the active part of the reel had a slightly fragile parabolic shape, and the required seeding rates - 24-48 pieces per linear meter (3.9-7.8 kilograms per hectare) - were provided with the length of the sowing reel 3.3-6.2 millimeters. It was proved that the seeder provided a high-quality formation of sowing ridges and irrigation furrows: the row spacing was 68.8 centimeters (installation spacing -70 centimeters), the top ridge width was 42.5 centimeters (the predetermined one was 40 centimeters), the depth of irrigation furrows was on average 9.6 centimeters. (Conclusions) A vegetable seeder was developed for sowing small-seeded vegetable crops with the simultaneous formation of sowing ridges and cutting irrigation furrows, which ensured high-quality performance of all operations and observance of onion seeds.
\end{abstract}

Keywords: vegetable seeder, sowing machine, onion seeds, sowing ridges formation, irrigation furrows, tape method of sowing, sowing rate, active part of the sowing reel.

IFor citation: Ibragimov A.A., Karakhanov A.K., Abdurakhmanov A.A., Eshdavlatov A.E., Uteniyazov P.A., Khadzhiev A.A. Rezul'taty issledovaniy novoy seyalki dlya vyseva semyan luka [Research results for a new onion seed drill]. Sel'skokhozyaystvennye mashiny i tekhnologii. 2020. Vol. 14. N4. 12-16 (In English). DOI 10.22314/2073-75992020-14-4-12-16.

\section{Результаты исследований новой сеялки для высева семян лука}

Абдирасули Абдикаримович Ибрагимов, доктор технических наук, старший научный сотрудник, e-mail: abirasul_82@mail.ru;

Асамиддин Караханович Караханов, кандидат технических наук, руководитель лаборатории; Абдукарим Атхамович Абдурахманов, кандидат технических наук, старший научный сотрудник, e-mail: 3abdukarim@mail.ru;
Акмал Эшпулатович Эшдавлатов, базовый докторант, e-mail: aeshdavlatov91@mail.uz;

Пулат Айтбаевич Утениязов, младший научный сотрудник, e-mail: paytbaev@list.ru;

Адхам Абдумуталибович Хаджиев, младший научный сотрудник, e-mail: adham.hadjiev@bk.ru

Научно-исследовательский институт механизации сельского хозяйства, г. Янгиюль, Республика Узбекистан 
Реферат. Для высева мелких семян овощей, в частности лука, используют специальные сеялки. В Республике Узбекистан их не производят, в то время как за рубежом выпускают множество различных пневматических сеялок. Отметили, что зарубежные образцы сложны по конструкции, не приспособлены к местным почвенно-климатическим условиям, не могут обеспечить равномерную заделку семян на гребнях, а стоимость самих сеялок и сервисного обслуживания очень высока. (Цель исследований) Разработать овощную сеялку применительно к почвенно-климатическим условиям Узбекистана, определить нормы высева семян лука в зависимости от длины активной части высевающей катушки, оценить качество формирования посевных гребней и поливных борозд. (Материаль и методы) Норму высева определяли путем прокручивания опорно-приводного колеса сеялки при заданной длине активной части высевающей катушки и сбора высеваемых семян в стаканчики с дальнейшим взвешиванием. Качество формирования посевных гребней и поливных борозд оценивали методом профилирования поля до и после прохода сеялки. (Результаты и обсуждение) Разработали овощную сеялку, выполняющую за один проход три операции: нарезку поливных борозд, формирование посевных гребней трапецеидальной формы и сев семян лука и других мелкосеменных овощных культур ленточным способом тремя рядами в каждой ленте. Выявили, что зависимость нормы высева от длины активной части катушки имеет слабовыраженную параболическую форму, а требуемые нормы высева - 24-48 штук на погонный метр (3,9-7,8 килограмма на гектар) - гарантированы при длине высевающей катушки 3,3-6,2 миллиметра. Доказали, что сеялка обеспечивает качественное образование посевных гребней и поливных борозд: ширина междурядий составила 68,8 сантиметра (установочная - 70 сантиметров), ширина гребней по верху равна 42,5 сантиметра (заданная - 40 сантиметров), глубина поливных борозд составила в среднем 9,6 сантиметра. $(B b l в o d b l)$ Разработали овощную сеялку для сева мелкосеменных овощных культур с одновременным формированием посевных гребней и нарезкой поливных борозд, обеспечивающую качественное выполнение всех операций и соблюдение норм высева семян лука.

Ключевые слова: овощная сеялка, высевающий аппарат, семена лука, формирование посевных гребней, поливные борозды, ленточный способ сева, норма высева, активная часть высевающей катушки.

I

ncreasing the level of vegetable crops cultivation is one of the important tasks facing the agrarians of the Republic of Uzbekistan. Onions play a significant role in the vegetables production [1-4]. For sowing its small seeds, special seeders are used. However, there is no local production of such machines, while many different pneumatic seeders are produced abroad. They provide accurate seeds sowing at a given depth in a row method [5-12]. But foreign samples are complex in design, and are not adapted to Uzbekistan soil and climatic conditions, and cannot provide even seed placement on the ridges. The cost of the seeders themselves and their service are very high. Therefore, farms and peasant households are forced to adapt other available technical means. In addition, the operations for preparing the soil and sowing seeds are carried out separately, which each time is accompanied by the units arrival on the field, unnecessary fuel and lubricants consumption, time and labor costs. All these increase the production cost $[6,13]$.

REsearch purpose is to develop a vegetable seeder in relation to the soil and climatic conditions of Uzbekistan, to determine the seeding rate of onion seeds depending on the length of the active part of the seed reel, to evaluate the formation quality of sowing ridges and irrigation furrows.

Materials AND METHOdS. Research Institute of Agricultural Mechanization developed a new seeder for sowing onions seeds and other small-seeded vegetable crops (Fig. 1). It performs a cutting irrigation furrows with the formation of trapezoidal sowing ridges and sowing seeds of onions or other small-seeded crops in a belt manner in three rows in each belt in one pass [14].

As the drill moves across the field, furrow cutters cut irrigation furrows and form ridges. The levelers cut the ridges top into a trapezoidal shape. The coulter runner seals the ridge top with a parallelogram spring. The plowshare opens the seed furrows to the required depth. The onion seeds are dosed by grooved seeding wheels and enter the seed tubes, and then move into the seed furrows. The closing working body in the form of a chain train covers the seeds with a thin soil layer. The markers are used to mark subsequent runs of the seed drill.

In two stages - in laboratory and in the field - a sowing unit, consisting of a T-25A tractor and a developed seeder, was tested (Fig. 2).

The authors studied the dependence of the onion seeds seeding rate on the length of the seeding wheel active part, which is changed by the movement of the latter relative to the apparatus body in laboratory conditions. The seeder was placed on stands so that the support-drive wheels rotated freely to simulate movement in the field. The sowing machines seed tubes were removed, and numbered cups were placed under the receiving funnels to collect the sown seeds. The seed drill was loaded with onion seeds. Then, setting a certain position of the seeding wheel along the length, sowing was carried out for 10 revolutions of the support-drive wheel, which was equivalent to the traveled distance of $12.56 \mathrm{~m}$ (wheel diameter $0.4 \mathrm{~m}$ ). The sown amount of seeds was weighed with an accuracy of 0.01 gram. Seeding was repeated 10 times for each position of the coil along the length. The length of the seeding wheel active part was $0 ; 5 ; 10 ; 15$ and $20 \mathrm{~mm}$.

The data were processed using the mathematical statistics methods $[15,16]$.

The seeding rate is determined by the formula:

$Q=\frac{10 q n}{B C}$, 
$a$
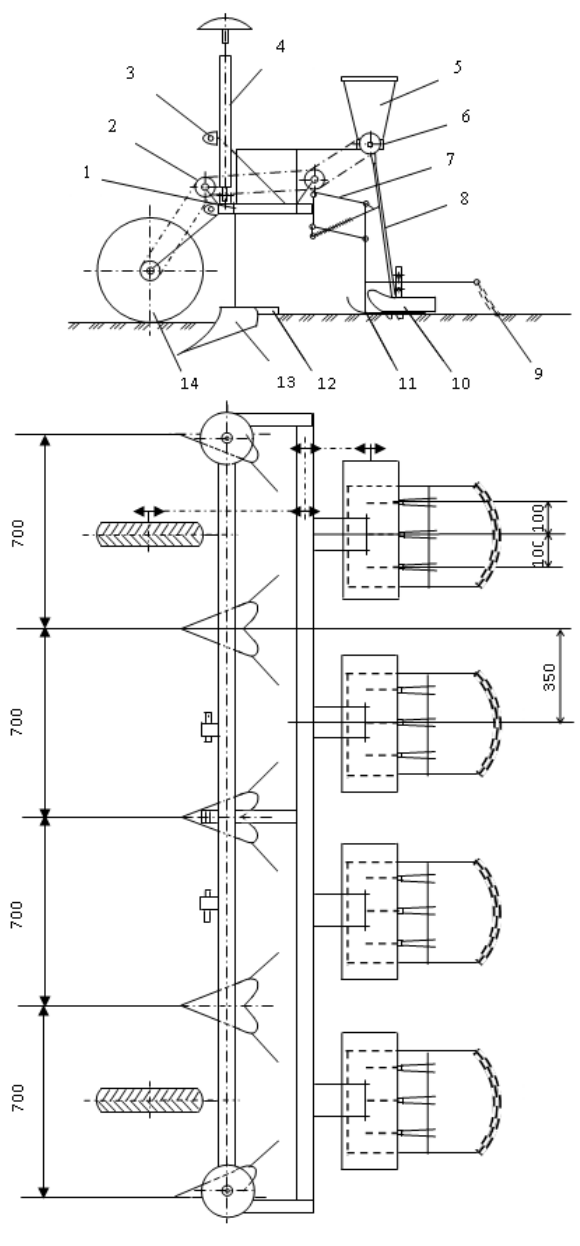

Fig. 1. Design of the vegetable seeder: $a$ - side view; $b$-top view 1 -frame; 2 -drive; 3 -three-point hitch; 4 -marker; 5 -hopper; 6 - sowing machine; 7 - parallelogram mechanism; 8 - seed holder; 9 - coverer; 10 - ploughshare; 11 - ploughshare runner; 12 - equalizer; 13 - furrow cutter ridge-divider; 14 - supporting drive wheel

where $Q$ is the seeder seeding rate, kilogram/ hectare;

10 - conversion factor;

$q$ - sowing seeds from 1 device for 1 revolution of the support-drive wheel, $\mathrm{g}$;

$n$-the number of seeding devices on the seeder, units;

$B$ - seeder seeding width, $\mathrm{m}$;

$C$ - the path length traversed in 1 revolution of the seeder support-drive wheel, $\mathrm{m}$.

Field trials were conducted to assess the quality of the formation of the seedbed and irrigation furrows. The field

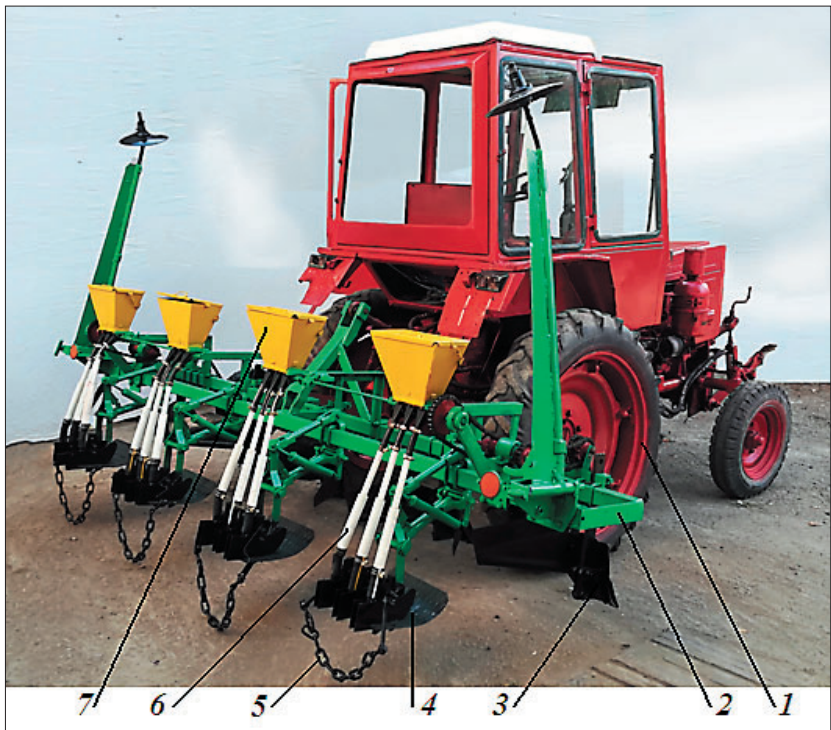

Fig. 2. Sowing unit for sowing small-seeded vegetable crops: 1 -tractor; 2 - seeder frame; 3 - furrow cutter-bed maker with leveler; 4 - runner with coulters; 5 - closing working body; 6 seed line; 7 - hopper

was prepared for sowing vegetable crops by harrowing with a heavy disc harrow BDT-3.0 to a depth of 18 centimeters. Then the surface soil layer was leveled and compacted using a small-leveler MV-6.5. The planter's furrow cutters were set at a row spacing of $70 \mathrm{~cm}$ with a depth of irrigation furrows of $10 \mathrm{~cm}$, the calculated ridges width at the top was $40 \mathrm{~cm}$.

After carrying out all the regulating work of the sowing unit and test drives, on the field section allocated for the registration drive, the transverse profile was examined using a special rod and ruler. Repetition of profile removal was 5 times. Then, the sowing unit made a registry drive over this area with the simultaneous formation of sowing ridges and irrigation furrows when sowing onion seeds using a belt method in three rows in each belt. After the unit pass, at the same places where the transverse profile of the field was determined before the unit pass, the transverse profiles of the obtained seed ridges and irrigation furrows were studied (Fig. 3).

Results AND DIscussion. At the first testing stage it was found that the seeding rate was directly proportional to the length of the seeding wheel active part: the longer the length of the wheel, the higher the seeding rate ( $t a-$ ble). So, the average seeding rate for three seeding devices of one row (ridge) with an active part length of $5 \mathrm{~mm}$

\begin{tabular}{|c|c|c|c|}
\hline \multicolumn{4}{|c|}{ DePENDENCE OF THE SEEDING ONION SEEDS RATE ON THE LENGTH OF THE REEL ACTIVE PART } \\
\hline $\begin{array}{c}\text { Length of the reel active } \\
\text { part, } \mathbf{~ m m}\end{array}$ & $\begin{array}{c}\text { Average seeding rate for } \\
\text { three machines, } \mathbf{g}\end{array}$ & $\begin{array}{c}\text { Variation coefficient of the seeding } \\
\text { rate between machines, } \%\end{array}$ & Seeder seeding rate, kg/ha \\
\hline 5 & 1.89 & 4.0 & 6.45 \\
\hline 10 & 3.91 & 2.8 & 13.34 \\
\hline 15 & 8.27 & 3.7 & 28.22 \\
\hline 20 & 11.63 & 2.7 & 39.68 \\
\hline
\end{tabular}




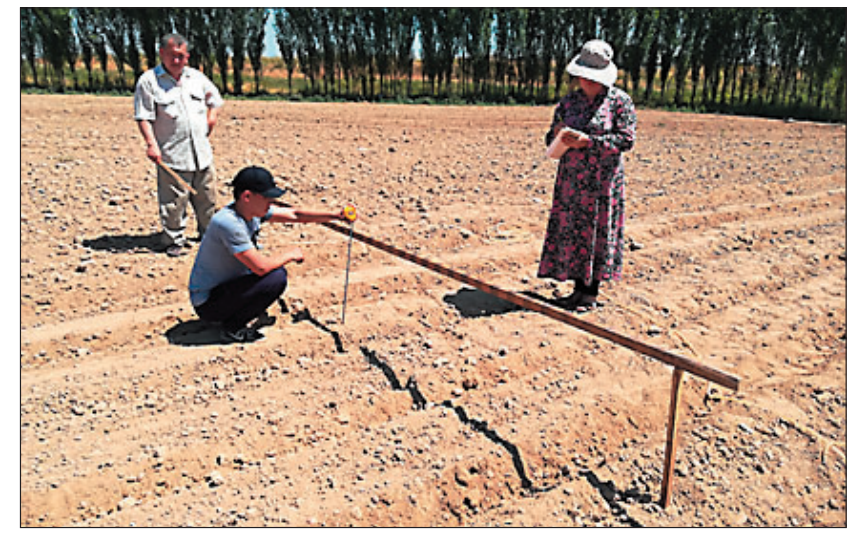

Fig. 3. Removing the profile after forming the ridges

for 10 revolutions of the support-drive wheel was 1.89 grams of seeds with a variation coefficient of $4 \%$.

The working width is $B=2.8 \mathrm{~m}$, the number of seeding devices on the seeder $n=12$ units, the length of the path covered in 1 revolution of the support-drive wheel, $C=1.256 \mathrm{~m}$. Consequently, the onion seeds seeding rate per hectare by a seeding device with parts of $5 \mathrm{~mm}$ will be $6.45 \mathrm{~kg} / \mathrm{ha}$. With the length of the seeding wheel active part of 20 millimeters, the onion seeds sowing was $11.63 \mathrm{~g}$ per running meter, or $39.68 \mathrm{~kg} / \mathrm{ha}$, and the coefficient of variation was $2.7 \%$.

The dependence of the seed drill reel device seeding rate on the length of the seeding wheel active part had a weakly expressed parabolic shape (Fig. 4). An empirical formula describing the above dependence was obtained by the least squares method $[15,16]$ :

$$
Q=0.0515 l^{2}+0.9935 l-0.1151,
$$

where $l$ - the length of the active part of the reel, $\mathrm{mm}$. According to the initial requirements, the seeding rate of small vegetable seeds with one device should be in the range of 24-48 pieces/running meter. In our case, when the seeder had a working width of $2.8 \mathrm{~m}$ and sowed 12 rows in 1 pass, this corresponded to the rate of $3.9-7.8 \mathrm{~kg} / \mathrm{ha}$ (the mass of 1000 pieces of onion seeds was on average $3.8 \mathrm{~g}$ ). For sowing onion seeds at the specified rates, the

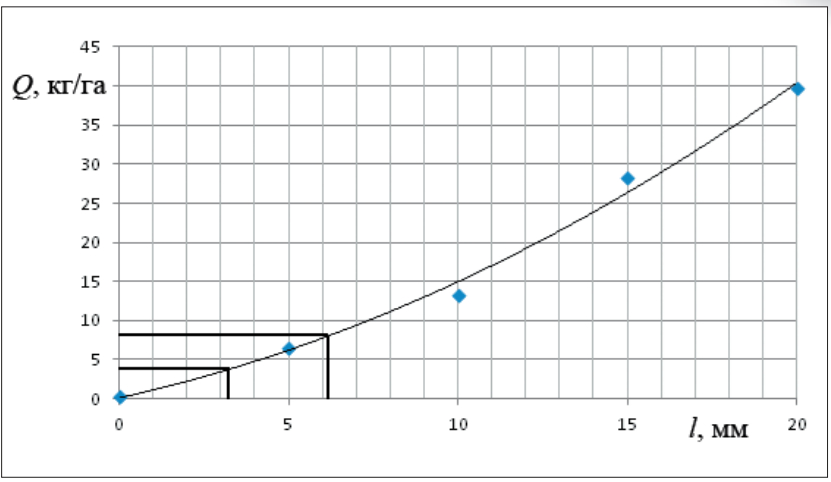

Fig. 4. Change in the seeding rate of onion seeds depending on the length of the active part of the seed reel

seeding wheel must have an active length within the range of 3.3-6.2 mm (Fig. 4).

According to the second stage of testing results, the formation quality of sowing ridges and irrigation furrows was assessed. In field experiments, the actual row spacing was $68.8 \pm 4.8 \mathrm{~cm}$ instead of the specified $70 \mathrm{~cm}$ (coefficient of variation $V=7.0 \%$ ). The ridges width at the top was on average $42.5 \pm 2.9 \mathrm{~cm}(V=6.8 \%)$. The irrigation furrows depth was on average $9.6 \pm 0.4 \mathrm{~cm}(V=4.3 \%)$. Observation of the seeder working process in the field showed that the furrow cutters with the leveler ensured the formation of trapezoidal seeding ridges and the cutting of irrigation furrows of the required quality.

The coulter runners additionally compacted the soil and flattened the ridges top by sowing onion seeds in three rows.

Conclusions. The developed vegetable seeder for sowing small-seeded vegetable crops with simultaneous formation of sowing ridges and irrigation furrows cutting is efficient, provides the specified seeding rates for onion seeds, high-quality cutting of seed ridges and irrigation furrows. Further research should be carried out in the direction of studying the seeder agrotechnical parameters with determining the sowing depth, its uniformity, as well as the distribution of seeds along the rows length.

\section{REFERENCES}

1. Toshboltaev M.T., Norchaev Zh.R. Obosnovanie parametrov sektsionnykh lemekhov lukokopatelya [Justification of the parameters of sectional shares of the onion digger]. Nauchno-tekhnicheskiy zhurnal FerPI. 2019. N1. 131-134 (In Russian).

2. Toshboltaev M.T., Norchaev Zh.R. Mashina dlya uborki luka-sevka [Machine for harvesting onion sets]. Mekhanizatsiya i elektrifikatsiya sel'skogo khozyaystva. 2016. N3. 100-102 (In Russian).

3. Toshboltaev M., Norchaev Zh. Obosnovanie parametrov bokovogo diska lukokopatelya [Justification of the parameters of the lateral disk of the onion digger]. Agro ilm. 2018. N2(52). 100-102 (In Russian).

4. Voss R.E., Murray M., Bradford K. et al. Onion seed production in California. University of California. Agriculture and Natural Resources. 2013. Vol. 4. Publication 8008 (In English).

5. Hoque M.A., Wohab M.A. Development and evaluation of a drum seeder for onion. Int. J. Agril. Res. Innov. \& Tech. 2013. N3(1). 23-28 (In English).

6. Abdurakhmanov A.A., Ibragimov A.A. State and problems of sowing onion seeds in Uzbekistan // Agro ilm. Tashkent: 2018. N2(58). 37-38 (In Russian).

7. Ignaciuk S., Zarajczyk J. Assessment of selected parameters of sowing quality of vistula parsley seeds with a precision seed drill with a pneumatic seeding system. Agricultural Engineering. 2020. Vol. 24. N2. 77-88 (In English).

8. Bozdogan A.M. Uniformity of within-row distance in pre- 
cision seeders: laboratory experiment. Journal of Applied Sciences. 2006. N6(10). 2281-2286 (In English).

9. Jadhav N.N., Aher H.R., Ghode A.P. Design and fabrication of onion seed sowing machine. International Journal on Recent Technologies in Mechanical and Automobile Engineering. 2015. Vol. 2. 1-10 (In English).

10. Rohokale A.B., Shewale P.D., Pokharkar S.B., et al. A review on multi-seed sowing machine. International Journal of Mechanical Engineering and Technology. 2014. Vol. 5. 180-186 (In English).

11. Swapnil T., Kasturi M.L., Girish P., Rajkumar P. Development and test of an electricprecision seeder for small-size vegetable seeds. International Research Journal of Engineering and Technology. 2017. Vol. 4. Iss. 9. 704-707 (In English).

12. Martin V., Madesh A., Karthick S., Kannan A. Design and fabrication of multipurpose sowing machine. International Journal of Scientific Engineering and Applied Science. 2015.

Конфликт интересов. Авторы заявляют об отсутствии конфликта интересов.
Vol. 1. Iss. 5. 27-34 (In English).

13. Dzhuraev A., Tukhtakuziev A., Mukhamedov Zh., Turdaliev V. Kombinirovannyy agregat dlya predposevnoy obrabotki pochvy i seva melkosemyannykh ovoshchnykh kul'tur. [Combined aggregate for pre-sowing tillage and sowing of small-seeded vegetables]. Tashkent: Fan va texnologiyalar. 2016. 180 (In Russian).

14. Ibragimov A., Abdurakhmanov A., Eshdavlatov A., Khadzhiev A. Seyalka dlya seva semyan luka [Seeder for sowing onion seeds]. Agro ilm. 2019. Spets. nomer (61). $78-79$ (In Russian).

15. Kobzar A.I. Applied Mathematical Statistics. For engineers and scientists. Moscow: Fizmatlit. 2006. 816 (In Russian).

16. Johnson N., Lyon F. Statistics and Experiment Planning in Engineering and Science. Data processing methods. Moscow: Mir. 1990. 610 (In Russian).

Conflict of interest. The authors declare no conflict of interest.
Статья поступила в редакцию 20.08.2020 The paper was submitted to the Editorial Office on 20.08.2020
Статья принята к публикации 03.11.2020

The paper was accepted for publication on 03.11.2020 